\title{
Identification and enzymatic characterization of acid phosphatase from Burkholderia gladioli
}

\author{
Tiago Henrique Rombola', Eliamar Aparecida Nascimbem Pedrinho', Eliana Gertrudes de Macedo Lemos',
} Adriano Marques Gonçalves ${ }^{1,2}$, Luiz Flávio José dos Santos ${ }^{1,2}$ and João Martins Pizauro Jr $r^{1,2^{*}}$

\begin{abstract}
Background: The genus Burkholderia is widespread in diverse ecological niches, the majority of known species are soil bacteria that exhibit different types of non-pathogenic interactions with plants. Burkholderia species are versatile organisms that solubilize insoluble minerals through the production of organic acids, which increase the availability of nutrients for the plant. Therefore these bacteria are promising candidates for biotechnological applications.

Results: Burkholderia sp. (R 3.25 isolate) was isolated from agricultural soil in Ponta Grossa-PR-Brazil and identified through analysis of the $16 \mathrm{~S}$ rDNA as a strain classified as Burkholderia gladioli. The expression of membrane-bound acid phosphatase (MBACP) was strictly regulated with optimal expression at a concentration of phosphorus $5 \mathrm{mM}$. The apparent optimum pH for the hydrolysis of $p$-nitrophenylphosphate (PNPP) was 6.0. The hydrolysis of PNPP by the enzyme exhibited a hyperbolic relationship with increasing concentration of substrate and no inhibition by excess of substrate was observed. Kinetic data revealed that the hydrolysis of PNPP exhibited cooperative kinetics with $\mathrm{n}=1.3, \mathrm{~V}_{\mathrm{m}}=113.5 \mathrm{U} / \mathrm{mg}$ and $\mathrm{K}_{0.5}=65 \mu \mathrm{M}$. The PNPPase activity was inhibited by vanadate, $p$-hydroxymercuribenzoate, arsenate and phosphate, however the activity was not inhibited by calcium, levamisole, sodium tartrate, EDTA, zinc, magnesium, cobalt, ouabain, oligomycin or pantoprazol.
\end{abstract}

Conclusion: The synthesis of membrane-bound non-specific acid phosphatase, strictly regulated by phosphate, and its properties suggest that this bacterium has a potential biotechnological application to solubilize phosphate in soils with low levels of this element, for specific crops.

Keywords: Phosphohydrolase, Inhibition, Phosphate, P-Nitrophenylphosphate, Solubilization

\section{Background}

The genus Burkholderia is widespread in diverse ecological niches; however, the majority of known species are soil bacteria that exhibit different types of non-pathogenic interactions with plants $[1,2]$. Following the pioneering work of Yabuuchi et al. [3], which described the Burkholderia genus, several investigators have studied Burkholderia species that are phylogenetically distant from the Burkholderia cepacia complex (Bcc species), which are promising candidates for biotechnological applications [4,2], although their environmental distribution and relevant characteristics for agro-biotechnological applications are not well known.

\footnotetext{
* Correspondence: jpizauro@fcav.unesp.br

${ }^{1}$ Faculdade de Ciências Agrárias e Veterinárias (FCAV), UNESP - Univ Estadual Paulista, Câmpus de Jaboticabal, Departamento de Tecnologia, Laboratório de Enzimologia Aplicada, Jaboticabal, SP, Brazil

${ }^{2}$ Instituto de Química (IQ), Univ Estadual Paulista, Câmpus de Araraquara, Araraquara, SP, Brazil
}

C Biomed Central
Burkholderia species are versatile organisms that solubilize insoluble minerals through the production of organic acids, which increase the availability of nutrients for the plant [5-7]. Interactions between plant roots and mineral phosphate solubilizing (MPS) microorganisms can play an important role in phosphorus nutrition and growth of most plants, microorganisms and crop production. As far as we know, the present report is the first systematic study to show that the membrane-bound acid phosphatase expressed by Burkholderia is strictly regulated by phosphorus. In addition, little is known about the enzyme's potential applications to improve plant growth by association with the bacteria.

Phosphorus is an essential nutrient that is required in large amounts to maintain levels of key cell molecules, including ATP, nucleic acids, and phospholipids; phosphorus is also a pivotal mediator in the regulation of many metabolic processes, such as energy transfer, 
protein activation, regulation of enzyme activities, gene activity control, as so in carbon and amino acid metabolic processes [8].

The uptake of nutrients from different natural environments depends on the secretion of an enormous variety of hydrolytic enzymes, which demonstrate catalytic activity that is specific for the cleavage of a particular substrate. This uptake process is tightly regulated and contains a variety of biochemical reactions that involve the acquisition, storage, and release of enzymes [9]. The study of these processes may provide new insights for the elucidation of gene expression that controls not only the synthesis but also the secretion of enzymes by eukaryotic cells in response to environmental factors, such as $\mathrm{pH}$ and levels of carbon, nitrogen, sulfur and phosphorus $[10,11]$.

In this paper, we report the expression and kinetic characterization of a membrane-bound acid phosphatase produced by Burkholderia gladioli that was isolated from the rhizosphere of Zea mays, which was collected from an agricultural soil in Ponta Grossa-PR-Brazil.

\section{Methods}

Isolation and identification of Burkholderia sp.

The isolation of Burkholderia sp. bacteria from surfacesterilized roots of Zea mays, which were collected from agricultural soil in Ponta Grossa-PR-Brazil, was described by Pedrinho et al. [12], and the bacteria was identified through partial 16S rRNA gene sequencing, using the specific oligonucleotides fD1 and rD1 [13].

The partial sequencing of the $16 \mathrm{~S}$ rRNA gene was performed by the use of 1,0 $\mu \mathrm{L}$ of DNA Sequencing-Big Dye Terminator Cycle Sequencing-Ready ABI Prism (Version 3); 3.2 pmols of $\mathrm{fD} 1 / \mathrm{rD} 1$ oligonucleotide, $60 \mathrm{ng}$ of DNA, $4.6 \mu \mathrm{L}$ of buffer $(400 \mathrm{mM}$ Tris- $\mathrm{HCl}, \mathrm{pH} 9 ; 10 \mathrm{mM}$ ( $\mathrm{MgCl} 2$ ); and mili-Q (Millipore) $\mathrm{H} 2 \mathrm{O}$ for a $10 \mathrm{~mL}$ volume.

The amplicons were sequenced using the model $\mathrm{ABI}$ 3100 capillary sequencer (Applied Biosystems, Foster City, CA, USA). The fasta sequence was analyzed by comparison using a local tool BLASTN [14] from NCBI (National Center of Biotechnology Information) and classified by RDP (Ribosomal Database Project).

The evolutionary history was inferred using the Neighbor-Joining method [15]. The optimal tree with the sum of branch length $=0.19803035$ is shown. The percentage of replicate trees in which the associated taxa clustered together in the bootstrap test (1000 replicates) are shown next to the branches [16]. The tree is drawn to scale, with branch lengths in the same units as those of the evolutionary distances used to infer the phylogenetic tree. The evolutionary distances were computed using the p-distance method [17] and are in the units of the number of base differences per site. The analysis involved 11 nucleotide sequences. Codon positions included were $1 s t+2 n d+3 r d+$ Noncoding. All positions containing gaps and missing data were eliminated. There were a total of 733 positions in the final dataset. Evolutionary analyses were conducted in MEGA5 [18]. The $16 \mathrm{~S}$ rDNA sequence obtained is registered at the International Gene Bank (GenBank), having the access number: JN 700991.

\section{Growth conditions and membrane-bound enzyme isolation}

Burkholderia sp. was grown in a liquid medium containing $2 \%$ glucose, $0.1 \%$ magnesium chloride, $0.025 \%$ magnesium sulfate, $0.1 \%$ ammonium sulfate, $0.02 \%$ potassium chloride, and with or without potassium phosphate. The liquid growth medium, prepared in 250-ml conical flasks, was incubated for $72 \mathrm{~h}$ at $30^{\circ} \mathrm{C}$ under constant rotary shaking at $140 \mathrm{rpm}$. Actively growing cells were collected by centrifugation, washed twice with $50 \mathrm{mM}$ sodium acetate buffer at $\mathrm{pH} 6.0$, resuspended in $8 \mathrm{~mL}$ of the same buffer and then disrupted by sonication at 50 microtips/ second with cycles of 30 seconds with a Branson Sonifier model 250 . The integral cells were removed by centrifugation at 5,000 g for $15 \mathrm{~min}$. The supernatant was subjected to a two-step differential centrifugation, first at $12,000 \mathrm{~g}$ and then for $1 \mathrm{~h}$ at $160,000 \mathrm{~g}$ to obtain soluble proteins and membrane bound enzyme. The pellet, which corresponds to the membrane-bound enzyme, was resuspended in the same buffer. Aliquots $(1.0 \mathrm{ml})$ were frozen in liquid nitrogen and stored at $-20^{\circ} \mathrm{C}$ without appreciable loss of activity when stored for less than 2 months.

\section{Enzymatic activity measurements}

Acid phosphatase activity was determined discontinuously at $37^{\circ} \mathrm{C}, 50 \mathrm{mM}$ acetate buffer, $\mathrm{pH}$ 6.0, through the formation of $p$-nitrophenolate $\left(\varepsilon=17600 \mathrm{M}^{-1} \mathrm{~cm}^{-1}\right.$, $\mathrm{pH} 13)$ at $410 \mathrm{~nm}$ from the hydrolysis of $1 \mathrm{mM} p$-nitrophenylphosphate $\left(\mathrm{SIGMA}^{\circ}\right)$. The enzymatic reaction was initiated by the addition of the enzyme extract to the reaction medium, interrupted by adding $1 \mathrm{ml}$ of $1 \mathrm{M}$ $\mathrm{NaOH}$, and the absorbance was determined at $410 \mathrm{~nm}$.

The determinations were performed in triplicates and the initial velocities remained constant during the incubation time to ensure that substrate hydrolysis was inferior to $5 \%$. In each determination standards were included to estimate the non-enzymatic hydrolysis of substrate.

A unit of enzyme activity was defined and expressed as the amount of enzyme that releases one nmol of $p$-nitrophenolate per minute, per milligram of protein present in the enzymatic extract, under test conditions.

\section{Thermal inactivation of membrane-bound acid phosphatase}

Samples of membrane-bound enzyme in $50 \mathrm{mM}$ acetate buffer at $\mathrm{pH} 6.0$ were incubated in a water bath at 
different temperatures for variable periods of time. Immediately after the water bath treatment, samples were chilled in an ice-water bath to stop the inactivation process, and the remaining PNPPase activity was assayed as described above.

\section{Effect of several compounds on the $p$-nitrophenylphosphatase activity}

Reactions were carried out in $50 \mathrm{mM}$ acetate buffer at $\mathrm{pH}$ 6.0, containing $1 \mathrm{mM}$ of PNPP and the following compounds: phosphate $(10 \mathrm{mM})$; EDTA $(10 \mathrm{mM})$; arsenate (1 $\mathrm{mM})$; magnesium (2 $\mathrm{mM})$; calcium (1 $\mathrm{mM})$; zinc (1 $\mathrm{mM})$; cobalt (1 $\mathrm{mM})$; levamisole $(10 \mathrm{mM})$; sodium tartrate $(10 \mathrm{mM})$; bafilomycin A1 (1 mM); oligomycin (1.5 $\mathrm{mg} / \mathrm{ml})$; ouabain $(1.3 \mathrm{mM})$; pantoprazol $(6 \mathrm{mM})$; PHMB (1 mM); and vanadate $(0.5 \mathrm{mM})$, in a final volume of $1.0 \mathrm{ml}$. The reaction was initiated by the addition of the enzyme and stopped by the addition of $1.0 \mathrm{ml}$ of 1.0 $\mathrm{M} \mathrm{NaOH}$ at the appropriate time. In each determination standards were included to estimate the nonenzymatic hydrolysis of substrate.

\section{Effect of pH on p-nitrophenylphosphate hydrolysis by membrane-bound acid phosphatase}

Assays were buffered with $50 \mathrm{mM}$ acetate for the $\mathrm{pH}$ range 3.5-6.5, and $50 \mathrm{mM}$ Tris- $\mathrm{HCl}$ for the $\mathrm{pH}$ range 6.5-8.0; each reaction contained $1 \mathrm{mM}$ of PNPP. There was no significant difference among the two buffers used at $\mathrm{pH} 6.5$. The $\mathrm{pH}$ before and after each kinetic determination did not differ by more than 0.05 units. The reaction was initiated by the addition of the membrane-bound enzyme and stopped with $1.0 \mathrm{ml}$ of $1.0 \mathrm{M} \mathrm{NaOH}$ at the appropriate time. In each determination standards were included to estimate the non-enzymatic hydrolysis of substrate.

\section{Determination of protein concentrations}

Protein concentrations were determined according to the method described by Hartree [19]. Bovine serum albumin was used as the standard in both cases.

\section{Estimation of kinetic parameters}

$\mathrm{V}, \mathrm{v}, \mathrm{K}_{0.5}$ and $\mathrm{n}$ obtained from substrate hydrolysis reactions were fit using a microcomputer as described by Pizauro et al. [20]. Data are reported as the mean of triplicate determinations that differed by less than $5 \%$.

\section{Results and discussion}

To quickly and reliably determine if the isolate belonged to the Burkholderia species, the amplified $16 \mathrm{~S}$ rDNA was compared with the most similar found in databases, and phylogenetic analysis showed that the strain belonged to a Burkholderia species (Figure 1). This isolate clustered with a set of Burkholderia strains classified as Burkholderia gladioli (GenBank BankIt accession n JN 700991).

Figure 2 shows the effect of increasing concentrations of phosphate in the medium used to grow Burkholderia gladioli. The acid phosphatase activity was maximal at $5 \mathrm{mM}$ phosphate, and reduced activity was observed when Burkholderia gladioli was grown in medium containing higher concentrations of phosphate. These results suggest that acid phosphatase in Burkholderia gladioli is synthesized exclusively under Pi-limiting conditions, which is characterized as Pi-repressible activity. The behaviors observed here show that acid phosphatase activity is downregulated by exogenous Pi concentration, suggesting that there is a tight coupling among the utilization of exogenous $\mathrm{Pi}$, mobilization of endogenous reserves, and derepression of acid phosphatase. In fact, several phosphatases from plant and fungal origins were shown to be induced by phosphate deficiency [21-24].

The benefits to use differential centrifugation to obtain the membrane-bound acid phosphatase is that this method is easy to reproduce, fast and highly reproducible. This method resulted in the separation of two fractions. The supernatant containing soluble proteins, which represented less than $5 \%$ of total activity and the pellet, corresponding to the membrane-bound enzyme, which represented more than $95 \%$ of total activity, and

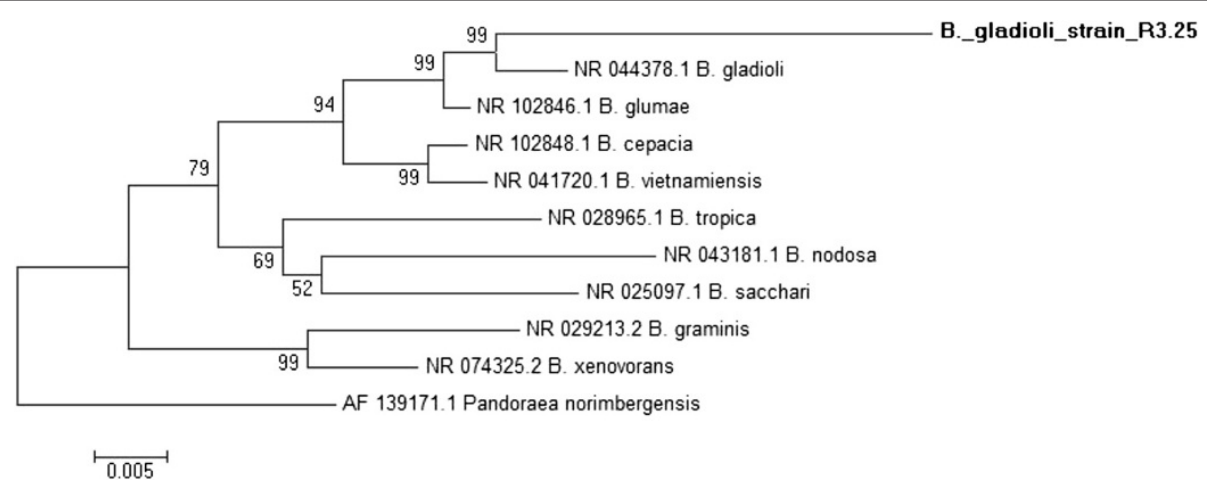

Figure 1 Dendrogram of the partial sequences of $16 \mathrm{~S}$ rDNA, proving the similarity of the isolated R 3.25 with Burkholderia gladioli. 


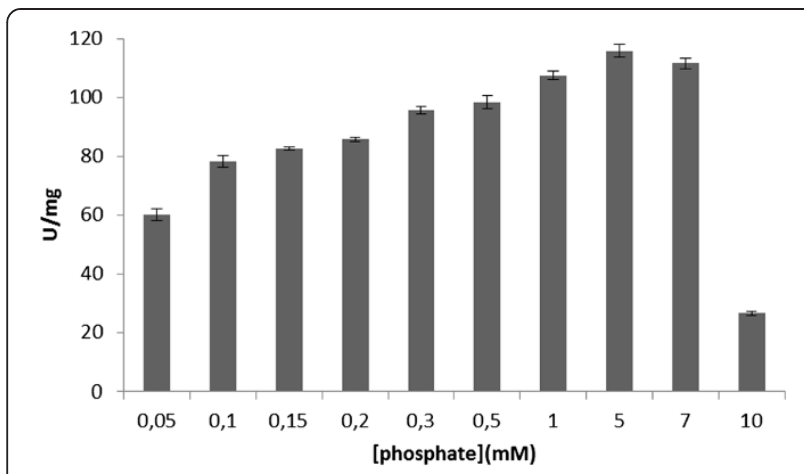

Figure 2 Expression of PNPPase activity of membrane-bound acid phosphatase in Burkholderia that was grown in medium containing increasing concentrations of phosphate.

showed specific activity of $103.9 \mathrm{U} / \mathrm{mg}$ for the chromogenic substrate; this fraction was used in further studies.

Membrane-bound enzyme was stable after $6 \mathrm{~h}$ of incubation at $45^{\circ} \mathrm{C}$ in $100 \mathrm{mM}$ acetate buffer at $\mathrm{pH}$ 6.0, but the enzyme was inactivated at higher temperatures, exhibiting a $\mathrm{t}_{1 / 2}$ that varied from $23 \mathrm{~h}$ at $50^{\circ} \mathrm{C}$ to $5 \mathrm{~min}$ at $70^{\circ} \mathrm{C}$. When the temperature was increased from $10^{\circ} \mathrm{C}$ to $70^{\circ} \mathrm{C}$, enzyme inactivation followed first order kinetics, and no break in the inactivation curves was observed from $10^{\circ} \mathrm{C}$ to $25^{\circ} \mathrm{C}$ (Figure 3), suggesting that this enzyme is associated with lipids in the membrane but is not an intrinsic membrane-bound enzyme [25]. This behavior is consistent with that reported for alkaline phosphatase from rat bone matrix-induced cartilage [26], which is anchored to the membrane by phosphatidylinositol $[27,28]$, and acid phosphatase with phytase activity from Mucor hiemalis [29]. In addition, according to Kondo et al. [30], acid phosphatase from

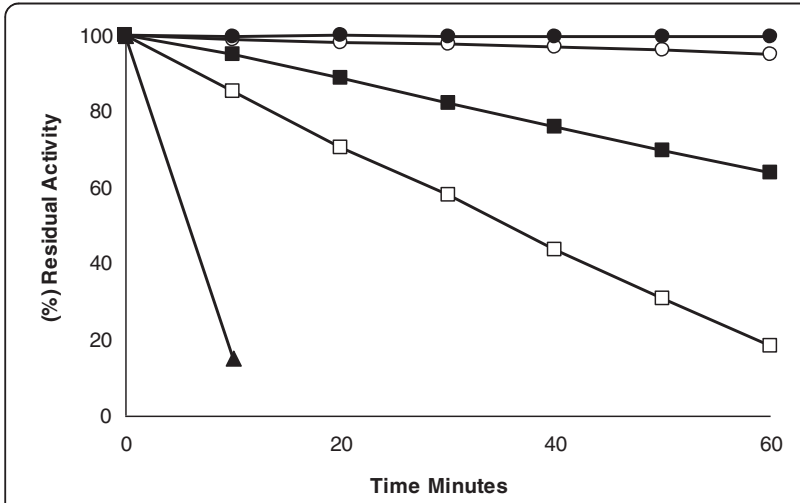

Figure 3 Thermal inactivation of membrane-bound acid phosphatase. The residual activity was determined by the addition of $50-\mu \mathrm{L}$ aliquots to $50 \mathrm{mM}$ acetate buffer, $\mathrm{pH}$ 6.0, containing $1 \mathrm{mM}$ PNPP, in a final volume of $1.0 \mathrm{ml}$. Values are the mean of triplicates determinations that differed by less than $5 \%$ variation. $(\bullet) 50^{\circ} \mathrm{C}$; $(\boldsymbol{\Delta})$ $70^{\circ} \mathrm{C}$; ( $60^{\circ} \mathrm{C}$; (口) $65^{\circ} \mathrm{C}$; (o) $55^{\circ} \mathrm{C}$. Inset: Arrhenius plot for the above data.
Burkholderia is a glycoprotein that is translocated during glycosylation from the cytoplasm to the outer membrane and then excreted into the environment.

The rate of hydrolysis of PNPP (Figure 4) by membrane-bound enzyme reached a maximum at $\mathrm{pH}$ 6.0, and this $\mathrm{pH}$ was selected as the incubation medium for the activity assays of acid phosphatase. This value for the optimum $\mathrm{pH}$ is similar to those reported for bacterial nonspecific acid phosphohydrolases [31], acid phosphatase from Aspergillus ficuum [21], and Burkholderia cepacia [32].

The hydrolysis of PNPP by the enzyme exhibited a hyperbolic relationship with increasing concentration of substrate and no inhibition by excess of substrate was observed. The specific activity of the enzyme for the hydrolysis of PNPP was $113.5 \mathrm{U} / \mathrm{mg}$ and $\mathrm{K}_{0.5}=65 \mu \mathrm{M}$ (Figure 5). Kinetic data revealed that the hydrolysis of PNPP exhibited cooperativity with $n=1.3$.

The ability of this enzyme to dephosphorylate phosphoesteres and the observed magnitudes of the kinetic values are consistent with those obtained for acid phosphatase from other sources [33,31]. In addition, the enzymatic properties of acid phosphatase were virtually identical to the acid phosphatase of E. histolytica [34], which catalyzes $p$-nitrophenylphosphate hydrolysis under acid $\mathrm{pH}$ conditions.

The effects of several compounds on $p$-nitrophenylphosphatase activity of the enzyme are shown in Table 1. EDTA and tartrate reagents that were present in concentrations up to $10 \mathrm{mM}$ showed only minor effects on enzymatic activity. The lack of inhibition by EDTA and sodium tartrate on PNPPase activity and the lack of dependence on magnesium, calcium, cobalt and zinc was also observed, suggesting that metal ions are not

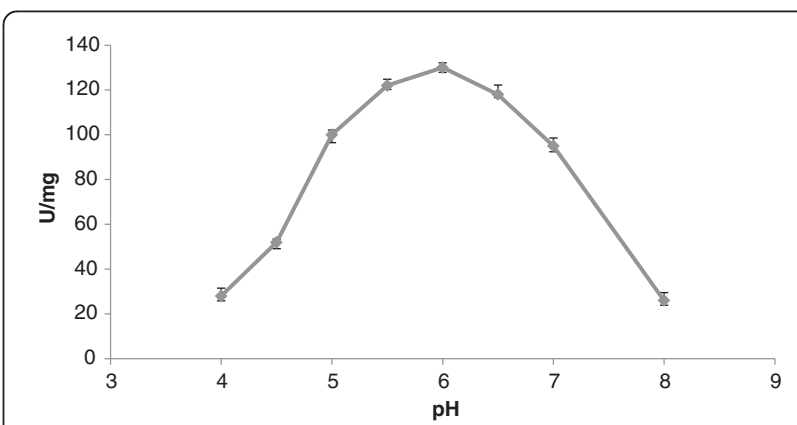

Figure $4 \mathrm{pH}$ sensitivity of the catalysis of membrane-bound acid phosphatase from Burkholderia gladioli. Enzymatic assays containing $1 \mathrm{mM}$ PNPP were buffered with $50 \mathrm{mM}$ acetate for the $\mathrm{pH}$ range $3.5-6.5$, and $50 \mathrm{mM}$ Tris- $\mathrm{HCl}$ for the $\mathrm{pH}$ range 6.5-8.0. There was no significant difference between the two buffers used at $\mathrm{pH}$ 6.5. The $\mathrm{pH}$ before and after each determination did not differ by more than 0.05 units, and the reaction was initiated by the addition of membrane-bound enzyme. 


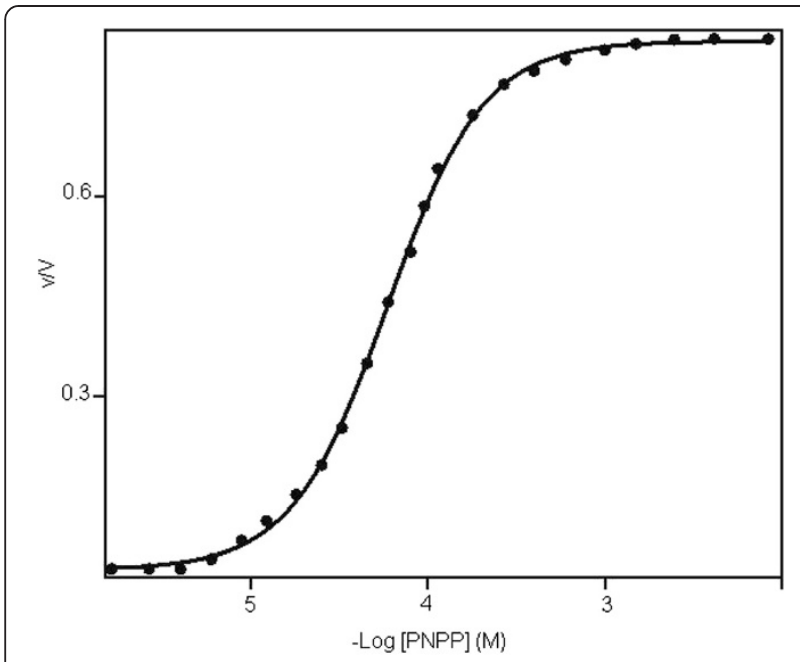

Figure 5 Effect of substrate concentration on phosphohydrolytic activity of membrane-bound acid phosphatase from Burkholderia gladioli. The PNPPase activity was assayed discontinuously at $37^{\circ} \mathrm{C}$. Standard assessment conditions were $50 \mathrm{mM}$ acetate buffer, $\mathrm{pH}$ 6.0, and containing increasing concentrations of substrate from $0.1 \mu \mathrm{M}$ to $10 \mathrm{mM}$.

involved in maintaining enzyme activity [35-37,26,38]. The significant inhibition observed for vanadate (94\%), does not imply, unequivocally, that this membranebound enzyme is a specific P-type ATPase. This interpretation is supported by the lack of inhibition by ouabain, which is an inhibitor of the $\mathrm{Na}^{+} / \mathrm{K}^{+}$-ATPase. Bafilomycin is also a highly specific inhibitor of vacuolar

Table 1 Relative effectiveness of several reagents on the activity of membrane-bound acid phosphatase from the R 3.25 isolate

\begin{tabular}{lc}
\hline Reagent & Residual activity \\
\hline Phosphate (10 mM) & 38 \\
EDTA (10 mM) & 95 \\
Arsenate (1 mM) & 14 \\
Magnesium (2 mM) & 96 \\
Calcium (1 mM) & 94 \\
Zinc (1 mM) & 97 \\
Cobalt (1 mM) & 94 \\
Levamisole (10 mM) & 93 \\
Sodium tartrate (10 mM) & 95 \\
Bafilomycin A1 (1 mM) & 98 \\
Oligomycin (1.5 mg/ml) & 93 \\
Ouabain (1.3 mM) & 92 \\
Pantoprazol (6 mM) & 95 \\
PHMB (1 mM) & 5 \\
Vanadate (0.5 mM) & 6 \\
\hline
\end{tabular}

Specific activity of $100 \%$ corresponds to $109.27 \mathrm{U} / \mathrm{mg}$.
$\mathrm{H}^{+}$-ATPases (V-ATPase) type in animal cells, plant cells and microorganisms [20] and does not inhibit the enzyme studied here. In addition, vanadate ions form a trigonal bipyramidal transition state at the active site of phosphatase, which bears some resemblance to the metastable intermediate occurring during the hydrolysis of phosphate esters [39]. Phosphate and arsenate are well known as inhibitors of acid phosphatase activity; the inhibition of PNPPase activity by phosphate and the more efficient inhibition by sodium arsenate, which is its structural analog, suggest a common mode of binding to the active site [40]. Similar to other phosphohydrolases, membrane-bound acid phosphatase is significantly inhibited by sodium orthovanadate $[41,42]$ and p-hydroxymercuribenzoate [43,44], which suggests that the sulfhydryl residue of cysteine is essential for its activity.

The main mechanism for mineral phosphate solubilization is the production of organic acids, and acid phosphatases play a major role in the mineralization of organic phosphorous in soil [45]. Considering that acid phosphatase is bound to the external membrane surface and therefore exposed to extracellular medium, our results bring an important insight on the mechanism of mineral phosphate solubilization by this bacterium and on plant nutrition through the increase in P uptake by the plant, mainly in soils with low levels of phosphate that are found in many regions of the world.

Although Burkholderia gladioli is known as a pathogen in some plant species [2] and causes opportunistic infection in severely immunocompromised humans [46], Bae [47] reported that a strain of this species have the ability to suppress pathologies caused by Pythium ultimum. In addition, B. gladioli has been described as a possible biofertilizer because of its capacity to fix nitrogen, mobilize phosphorus and stimulate plant growth [48-50]. It should be emphasized that B. gladioli also promotes beneficial effects as plant growth and nitrogen fixation in sugarcane crops [50]. Therefore, it may be possible to use this bacterium as a biofertilizer for specific crops, besides biochemical studies can contribute to elucidate its mechanisms.

\section{Conclusion}

Through analysis of the $16 \mathrm{~S}$ rDNA our strain was classified as Burkholderia gladioli (GenBank BankIt accession $\mathrm{n}^{\circ}$ JN 700991), therefore, phylogenetically distant from the Burkholderia cepacia complex (Bcc species). The synthesis of membrane-bound non-specific acid phosphatase, strictly regulated by phosphate, and its properties suggest that this bacterium has a potential biotechnological application to solubilize phosphate in soils with low levels of this element for specific crops. 


\section{Competing interests}

The authors declare that they have no competing interests.

\section{Authors' contributions}

THR executed the enzymatic assays and enzyme extraction and analyzed the data, along with AMG and LFJS. EANP and EGML performed the genetic studies and analysis. JMPJ conceived of the study and wrote the manuscript. All authors read and approved the final manuscript.

\section{Acknowledgements}

This research was supported by FAPESP and CNPq. We would like to thank Dra. Silvana Pompéia Val-Moraes for the reading and scientific advice.

Received: 7 November 2013 Accepted: 26 March 2014 Published: 9 April 2014

\section{References}

1. Coenye T, Vandamme P: Diversity and significance of Burkholderia species occupying diverse ecological niches. Environ Microbiol 2003, 5(9):19-29.

2. Compant S, Nowak J, Coenye T, Clément C, Ait Barka E: Diversity and occurrence of Burkholderia spp. in the natural environment. FEMS Microbiol Rev 2008, 32(4):607-626.

3. Yabuuchi E, Kosako Y, Oyaizu H, Yano I, Hotta H, Hashimoto Y, Ezaki T, Arakawa M: Proposal of Burkholderia gen. nov. and transfer of seven species of the genus Pseudomonas homology group II to the new genus, with the type species Burkholderia cepacia Palleroni and Holmes 1981. Microbiol Immunol 1992, 36:1251-1275.

4. Caballero-Mellado J, Onofre-Lemus J, Estrada de LosSantos P, Martínez-Aguilar L: The tomato rhizosphere, an environment rich in nitrogen-fixing Burkholderia species with capabilities of interest for agriculture and bioremediation. Appl Environ Microbiol 2007, 73(16):5308-5319.

5. Barea JM, Pozo MJ, Azcón R, Azcón-Aguilar C: Microbial co-operation in the rhizosphere. J Exp Bot 2005, 56(417):1761-1778.

6. Lin TF, Huang HI, Shen FT, Young CC: The protons of gluconic acid are the major factor responsible for the dissolution of tricalcium phosphate by Burkholderia cepacia CC-Al74. Bioresour Technol 2006, 97(7):957-960.

7. Song OR, Lee SJ, Lee YS, Lee SC, Kim KK, Choi YL: Solubilization of insoluble inorganic phosphate by Burkholderia cepacia DA23 isolated from cultivated soil. Braz J Microbiol 2008, 39(1):151-156.

8. Li L, Qiu X, Li X, Wang S, Lian X: The expression profile of genes in rice roots under low phosphorus stress. Sci China Life Sci 2009, 52(11):1055-1064.

9. Torriani-Gorini A: Regulation of phosphate metabolism and transport. In Phosphate in microorganisms: cellular and molecular biology. Edited by Torriani-Gorini A, Yagil E, Silver S. Washington D.C: American Society for Microbiology; 1994:1-4.

10. Caddick MX, Brownlee AG, Arst JRHN: Phosphatase regulation in Aspergillus nidulans: Responses to nutritional starvation. Genet Res 1986, 47:93-102.

11. Nozawa SR, Maccheroni JW, Stábeli RG, Thedei JG, Rossi A: Purification and properties of pi-repressible acid phosphatases from Aspergillus nidulans. Phytochemistry 1998, 49(6):1517-1523.

12. Pedrinho EAN, Galdiano-Júnior RF, Campanharo JC, Carareto-Alves LM, Lemos EGM: Identificação e avaliação de rizobactérias isoladas de raízes de milho. Bragantia 2010, 69(4):905-911.

13. Weisburg WG, Barns SM, Pelletier DA, Lane DJ: $16 \mathrm{~S}$ ribossomal DNA amplification for phylogenetic study. J Bacteriol 1991, 173(2):697-703.

14. Astschul SF, Madden TL, Schaffer AA, Zhang J, Zhang Z, Miller W, Lipman DJ: Gapped BLAST and PSI-BLAST: a new generation of protein database search programs. Nucleic Acids Res 1997, 25(17):3389-3402.

15. Saitou N, Nei M: The neighbor-joining method: a new method for reconstructing phylogenetic trees. Mol Biol Evol 1987, 4:406-425.

16. Felsenstein J: Confidence limits on phylogenies: an approach using the bootstrap. Evolution 1985, 39:783-791.

17. Nei M, Kumar S: Molecular Evolution and Phylogenetics. New York: Oxford University Press; 2000.

18. Tamura K, Peterson D, Peterson N, Stecher G, Nei M, Kumar S: MEGA5: molecular evolutionary genetics analysis using maximum likelihood, evolutionary distance, and maximum parsimony methods. Mol Biol Evol 2011, 28:2731-2739.
19. Hartree EF: Determination of protein: a modification of the Lowry method that gives a linear photometric response. Anal Biochem 1972, 48:422-427.

20. Pizauro JM, Demenis MA, Ciancaglini $P$, Leone FA: Kinetic characterization of a membrane-specific ATPase from rat osseous plate and its possible significance on endochondral ossification. Biochemica et Biophysics Acta-Biomembranes 1998, 1368(1):108-114.

21. Ullah AH, Cummins BJ: Aspergillus ficuum extracellular pH 6.0 optimum acid phosphatase: purification, $\mathrm{N}$-terminal amino acid sequence, and biochemical characterization. Prep Biochem 1988, 18(1):37-65.

22. Olczak M, Morawiecka B, Watorek W: Plant purple acid phosphatases-genes, structures and biological function. Acta Biochemica Polonica 2003, 50:1245-1256.

23. Lung SC, Leung A, Kuang R, Wang Y, Leung P, Lim BL: Phytase activity in tobacco Nicotiana tabacum root exudates is exhibited by a purple acid phosphatase. Phytochemistry 2008, 69(2):365-373.

24. Yeung SL, Cheng C, Lui TKO, Tsang JSH, Chan W, Lim BL: Purple acid phosphatase-like sequences in prokaryotic genomes and the characterization of an atypical purple alkaline phosphatase from Burkholderia cenocepacia J2315. Gene 2009, 440:1-8.

25. Barton $\mathrm{PL}$, Futerman $\mathrm{AH}$, Silman I: Arrhenius plots of acetylcholinesterase activity in mammalian erythrocytes and in Torpedo electric organ. Effect of solubilization by proteinases and by a phosphatidylinositol-specific phospholipase C. Biochem J 1985, 231:237-240.

26. Curti C, Pizauro JM, Ciancaglini P, Leone FA: Kinetic characteristic of some inhibitors of matrix-induced alkaline phosphatase. Cell Mol Biol 1987, 33:625-635.

27. Pizauro JM, Ciancaglini P, Leone L: Osseous Plate alkaline phosphatase is anchored by GPI. Braz J Med Biol Res 1994, 27:453-456.

28. Pizauro JM, Ciancaglini P, Leone FA: Characterization of the hosphatidylinositol-specific phospholipase C-released form of rat osseous plate alkaline phosphatase and its possible significance on endochondral ossification. Mol Cell Biochem 1995, 152(2):121-129.

29. Boyce A, Walsh G: Purification and characterization of an acid phosphatase with phytase activity from Mucor hiemalis Wehmer. J Biotechnol 2007, 132(1):82-87.

30. Kondo E, Kurata T, Naigowit P, Kanai K: Evolution of cell-surface acid phosphatase of Burkholderia pseudomallei. Southeast Asian J Trop Med Public Health 1996, 27:592-599.

31. Rossolini GM, Schippa S, Riccio ML, Berlutti F, Macaskie LE, Thaller MC: Bacterial nonspecific acid phosphohydrolases: physiology, evolution and use as tools in microbial biotechnology. Cell Mol Life Sci 1998, 54(8):833-850.

32. Ferreira AS, Leitão JH, Sousa SA, Cosme AM, Sá-Correia I, Moreira LM: Functional Analysis of Burkholderia cepacia Genes BCED and bceF, Encoding a Phosphotyrosine Phosphatase and a Tyrosine Autokinase, Respectively: Role in Exopolysaccharide Biosynthesis and Biofilm Formation. ApplEnviron Microbiol 2007, 73(2):524-534.

33. Toh-E A, Ueda Y, Kakimoto SI, Oshima Y: Isolation and characterization of acid phosphatase mutants in Saccharomyces cerevisiae. J Bacteriol 1973, 113(2):727-738.

34. Anaya-Ruiz M, Pérez-Santos JL, Talamás-Rohana P: An ecto-protein tyrosine phosphatase of Entamoeba histolytica induces cellular detachment by disruption of actin filaments in HeLa cells. Int J Parasitol 2003, 33(7):663-670.

35. Anderson RA, Bosron WF, Kennedy FS, Vallee BL: Role of magnesium in Escherichia coli alkaline phosphatase metal content/metalloenzyme regulation/spectral properties/tritium exchange. Proc Natl Acad Sci USA 1975, 72:2989-2999.

36. Mccomb RB, Bowers GN, Posen S: Alkaline phosphatase. New York: Plenum Press; 1979.

37. Fortuna R, Anderson HC, Carty R, Sajdera SW: Enzymatic characterization of the matrix vesicle alkaline phosphatase isolated from bovine fetal epiphyseal cartilage. Calcif Tissue Int 1980, 30(1):217-225.

38. Ciancaglini P, Pizauro JM, Grecchi MJ, Curti C, Leone FA: Effect of Znll and Mgll on phosphohydrolytic activity of rat matrix-induced alkaline phosphatase. Mol Cell Biol 1989, 35:503-510.

39. Lopez V, Stevens T, Lindquist RN: Vanadium ion inhibition of alkaline phosphatase-catalyzed phosphate ester hydrolysis. Arch Biochem Biophys 1976, 175(1):31-38.

40. Durmus A, Eicken C, Sift BH, Kratel A, Kappl R, Hüttermann J, Krebs B: The active site of purple acid phosphatase from sweet potatoes Ipomoea batatas Metal content and spectroscopic characterization. Eur J Biochem 1999, 260(3):709-716. 
41. Fukami Y, Lipmann F: Purification of a specific reversible tyrosineO-phosphate phosphatase. Proc Natl Acad Sci USA 1982, 79:4275-4279.

42. Lau KHW, Farley JR, Baylink DJ: Phosphotyrosyl-specific protein phosphatase activity of a bovine skeletal acid phosphatase isoenzyme. Comparison with the phosphotyrosyl protein phosphatase activity of skeletal alkaline phosphatase. J Biol Chem 1985, 260:4653-4660.

43. Granjeiro JM, Ferreira CV, Jucá MB, Taga EM, Aoyama H: Bovine kidney low molecular weight acid phosphatase: FMN-dependent kinetics. Biochem Mol Biol Int 1997, 41:1201-1206.

44. Buzalaf MAR, Granjeiro JM, Ferreira CV, Lourenção VA, Ortega MM, Poletto DW: Kinetic characterization of bovine lung lowmolecular-weight protein tyrosine phosphatase. Exp Lung Res 1998, 24(3):269-272.

45. Rodríguez $H$, Fraga R: Phosphate solubilizing bacteria and their role in plant growth promotion. Biotechnol Adv 1999, 17(4-5):319-339.

46. Graves M, Robin T, Chipman AM: Four additional cases of Burkholderia gladioli infection with microbiological correlates and review. Clin Infect Dis 1997, 25(4):838-842.

47. Bae YS, Park K, Choi OH: Laboratory culture media-dependent biocontrol ability of Burkholderia gladioli strain B543. Plant Pathol J 2007, 23(3):161-165.

48. Babalola OO, Akindolire AM: Identification of native rhizobacteria peculiar to selected food crops in Mmabatho municipality of South Africa. Biol Agric Hortic An International Journal for Sustainable Production Systems 2011, 27(3-4):294-309

49. Mamta P, Rahi R, Pathania V, Gulati A, Singh B, Bhanwra RK, Tewari R: Stimulatory effect of phosphate-solubilizing bacteria on plant growth, stevioside and rebaudioside-A contents of Stevia rebaudiana Bertoni. App/ Soil Ecol 2010, 46:222.

50. Pereira APA, Silva MCB, Oliveira JRS, Ramos APS, Freire MBGS, Freire FJ, Kuklinsky-Sobral J: Salinity influence on the growth and production of indole acetic acid by endophytic Burkholderia spp. from sugarcane. Bioscience J 2012, 28(1):112-121.

doi:10.1186/1756-0500-7-221

Cite this article as: Rombola et al: Identification and enzymatic

characterization of acid phosphatase from Burkholderia gladioli. BMC

Research Notes 2014 7:221.

\section{Submit your next manuscript to BioMed Central and take full advantage of:}

- Convenient online submission

- Thorough peer review

- No space constraints or color figure charges

- Immediate publication on acceptance

- Inclusion in PubMed, CAS, Scopus and Google Scholar

- Research which is freely available for redistribution 